TAO, Vol. 16, No. 2, 445-465, June 2005

\title{
Seasonal Variability of Carbon Chemistry at the SEATS Time-Series Site, Northern South China Sea Between 2002 and 2003
}

\author{
Wen-Chen Chou ${ }^{1,2, *}$, David Der-Duen Sheu', Chen-Tung Arthur Chen ${ }^{1}$, \\ Shu-Lun Wang ${ }^{3}$ and Chun-Mao Tseng ${ }^{4}$
}

(Manuscript received 17 September 2004, in final form 13 April 2005)

\begin{abstract}
Analyses of total carbon dioxide ( $\left.\mathrm{TCO}_{2}\right)$ and titration alkalinity (TA) in the mixed-layer was performed approximately bimonthly at the SEATS time series site $\left(1^{\circ} 15, \mathrm{~N}, 1^{\circ} 5^{\circ} 35^{\prime} \mathrm{E}\right)$ in the northern South China Sea (SCS) from March 2002 to April 2003. These measurements and the calculated$\mathrm{fCO}_{2}$ were then used to document their seasonal variations and to estimate the seasonal air-sea flux of $\mathrm{CO}_{2}$ during the observed period at the site. Results show that the normalized $\mathrm{TCO}_{2}\left(\mathrm{NTCO}_{2}=\mathrm{TCO}_{2} \times 35 / \mathrm{S}\right)$ fluctuates seasonally between $\sim 1972$ and $\sim 1997 \mu \mathrm{mol} \mathrm{kg}^{-1}$, with the highest value in winter. The decline of $\mathrm{NTCO}_{2}$ in spring-summer mainly results from in situ biological utilization, while the resurgence of $\mathrm{NTCO}_{2}$ in fall-winter is due to entrainment of the $\mathrm{TCO}_{2}$-rich subsurface waters from below. TA varies from $\sim 2190$ to $\sim 2220 \mu \mathrm{mol} \mathrm{kg}{ }^{-1}$ in tandem with salinity, suggesting the prime control of physical processes. $\mathrm{fCO}_{2}$ increases progressively from spring to summer, reaches a maximum in July ( $382 \mu \mathrm{atm})$, then decreases from fall to winter to a minimum $(\sim 347 \mu$ atm $)$ in January with an amplitude of $\sim 35 \mu \mathrm{atm}$. The seasonal variability of $\mathrm{fCO}_{2}$ is in phase with temperature changes but is inversely correlated with the fluctuation of $\mathrm{NTCO}_{2}$, suggesting that the $\mathrm{fCO}_{2}$ seasonality is primarily controlled by temperature changes, though other factors have compensated partially to yield the

\footnotetext{
${ }^{1}$ Institute of Marine Geology and Chemistry, National Sun Yat-Sen University, Kaohsiung, Taiwan, $\mathrm{ROC}$

${ }^{2}$ National Center for Ocean Research-Kaohsiung Branch, National Sun Yat-Sen University, Kaohsiung, Taiwan, ROC

${ }^{3}$ Department of Marine Environmental Engineering, National Kaohsiung Marine University, Kaohsiung, Taiwan, ROC

${ }^{4}$ National Center for Ocean Research, P.O. Box 23-13, Taipei, Taiwan, ROC

* Corresponding author address: Dr. Wen-Chen Chou, Institute of Marine Geology and Chemistry, National Sun Yat-Sen University, Kaohsiung, Taiwan, ROC; E-mail: wcjou@mail.nsysu.edu.tw
} 
observed low amplitude of its variability. The sea-to-air $\mathrm{CO}_{2}$ fluxes for spring, summer, fall and winter are estimated to range from $0.00 \pm 0.01$ to $-0.02 \pm 0.05,+0.03 \pm 0.01$ to $+0.23 \pm 0.06,+0.18 \pm 0.10$ to $+0.45 \pm 0.25$, and $-0.62 \pm 0.20$ to $-1.42 \pm 0.46 \mathrm{molC} \mathrm{m}^{-2}$ year $^{-1}$, respectively. Throughout the year, the annual flux is calculated to be $-0.11 \pm 0.08 \sim-0.23 \pm 0.18$ molC $\mathrm{m}^{-2}$ year $^{-1}$ during the observed period. Furthermore, although there is a drawdown of $\mathrm{NTCO}_{2}$ of $\sim 25 \mu \mathrm{mol} \mathrm{kg}{ }^{-1}$ from winter to summer, which implies a net community production of $6.80 \pm 0.77 \mathrm{mmolC} \mathrm{m}^{-2}$ year $^{-1}$ in the mixed layer at the SEATS site, there is no corresponding change of nitrate observed, suggesting other sources of nitrogen required to sustain the new production.

(Key words: Carbon dioxide, Air-sea flux, Time-series, South China Sea)

\section{INTRODUCTION}

In response to growing concern over the role of oceanic uptake of increasing atmospheric $\mathrm{CO}_{2}$ concentration, enormous research efforts have been made to better quantify the spatial and temporal variability of $\mathrm{CO}_{2}$ fluxes between the atmosphere and the oceans. Among these, the most direct method to unravel the temporal variations of $\mathrm{CO}_{2}$ fluxes is to carry out longterm time-series measurements in the world's oceans. For instance, the Bermuda Atlantic Time-series Study (BATS; $31^{\circ} 50^{\prime} \mathrm{N}, 6^{\circ} 10^{\prime} \mathrm{W}$ ) and the Hawaii Ocean Time-series program (HOT; $22^{\circ} 45^{\prime} \mathrm{N}, 158^{\circ} 00^{\prime} \mathrm{W}$ ) were established in the subtropical Atlantic and Pacific during the late 1980s, respectively. Results from these long-term oceanic time-series observations have helped scientists to better understand processes modulating the $\mathrm{CO}_{2}$ exchange between the atmosphere and the upper oceans (Winn et al. 1994; 1998; Bates et al. 1996; Bates 2001; Gruber et al. 2002; Dore et al. 2003). The general consensus has been that the temperate and polar oceans of both hemispheres act as major sinks for atmospheric $\mathrm{CO}_{2}$, while the equatorial oceans are major sources for $\mathrm{CO}_{2}$. Furthermore, in terms of the processes controlling seasonal amplitude of surface-water $\mathrm{fCO}_{2}$, the biological effect is shown to be dominant in high-latitude and equatorial waters, whereas in the temperate gyre regions it is dominated by the temperature effect (Takahashi et al. 1993; 1997; 2002). However, in order to gain a better air-sea $\mathrm{CO}_{2}$ flux scenario on a global scale, time-series observations from other key regions in the world's oceans is required (Feely et al. 2001; Karl et al. 2001; Quay, 2002). Thus, the establishment and subsequent study of the South East Asia Time-series Study site (SEATS; $18^{\circ} 15^{\prime} \mathrm{N}, 115^{\circ} 35^{\prime} \mathrm{E}$; Fig. 1) in the northern South China Sea (SCS) are timely needed, because it is the only one time-series station situated in a subtropical marginal sea (Shiah et al. 1999; Karl et al. 2003).

The SCS, one of the largest marginal seas in the world ocean, is a semi-enclosed marginal sea off the Asian continent in the West Pacific. Previous studies have revealed intensive upwelling and vertical mixing in the SCS (Chen and Huang 1995; Chao et al. 1996). The upwelling of deep water brings nutrient-laden water closer to the surface, thus nutricline in the 


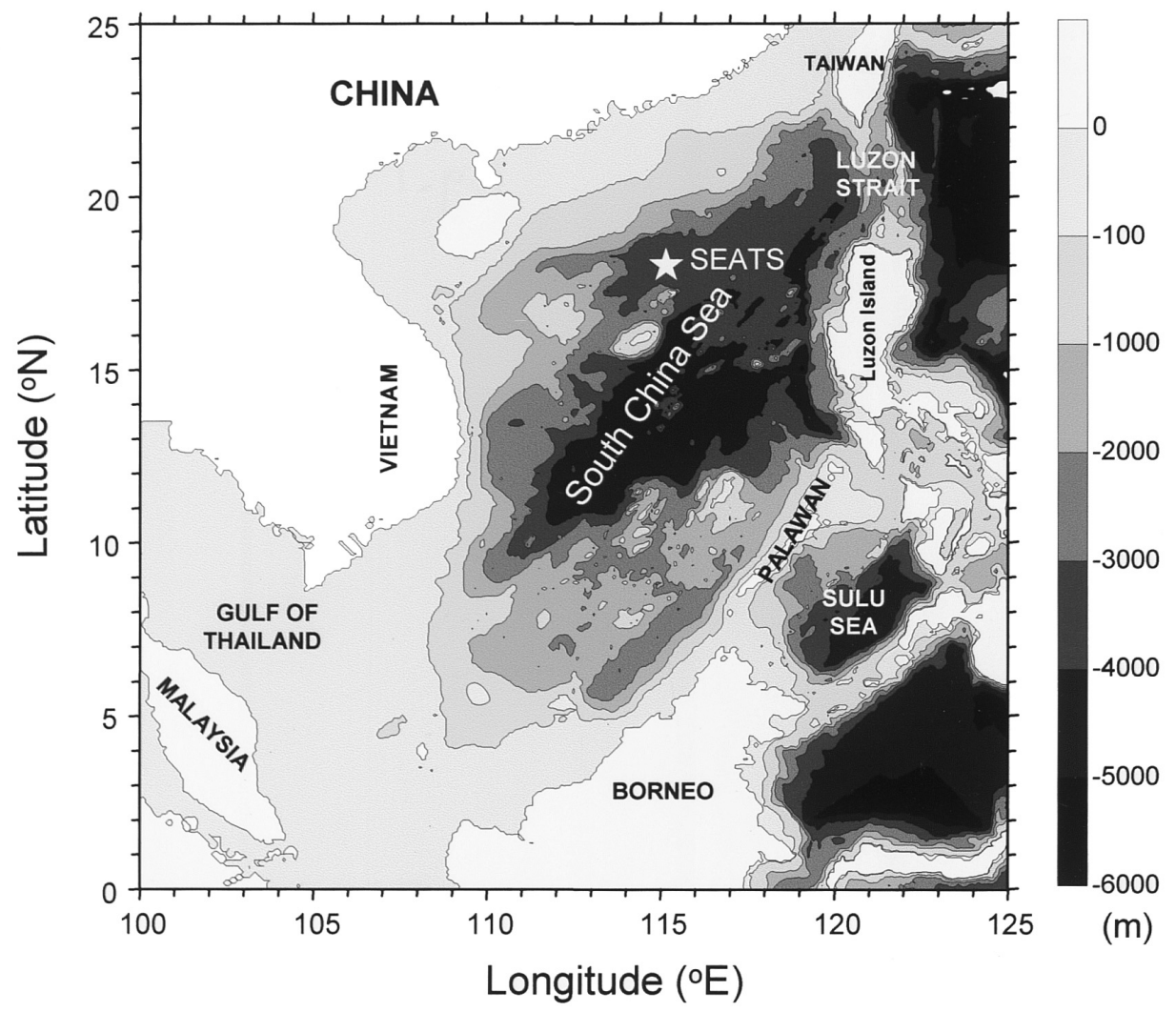

Fig. 1. Bathymetric map showing the location of the SEATS (South East Asia Time-series Study) time-series site $\left(18^{\circ} 15^{\prime} \mathrm{N}, 115^{\circ} 35^{\prime} \mathrm{E}\right)$ at a water depth of $\sim 3770 \mathrm{~m}$ in the northern South China Sea.

SCS is much shallower and its chlorophyll level in surface water is twice as high as those in the adjacent western North Pacific (Gong et al. 1992; Liu et al. 2002). In addition, several studies suggest that the seasonality of biogeochemical cycles is affected profoundly by the alternate monsoon system prevailing in the SCS. For instance, both modeled and SeaWiFSderived primary production show a winter maximum during the stronger northeast monsoon and a summer minimum during the weaker southwest monsoon (Liu et al. 2002). Wong et al. (2002) reported that the concentrations of nitrate anomaly in the upper nutricline were systematically higher in fall through early spring during the northeast monsoon than in the summer during the southwest monsoon. The authors suggest that this phenomenon could be the result of higher nitrogen fixation during the northeast monsoon period. The objectives of this study are to document the carbon system in the mixed-layer, to calculate the seasonal variations of $\mathrm{CO}_{2}$ flux, and to delineate the processes controlling its variability at the SEATS site over an annual cycle from March 2002 to April 2003. 


\section{METHODS}

\subsection{Sampling and Analysis}

During the course of this study, the SEATS site was investigated aboard the R/V Ocean Research I and III in March, July, September, and November 2002, as well as January, March, and April 2003. On board, temperature and salinity were recorded with a CTD (SeaBird Inc. model 911 plus). All raw data and other pertinent measurements are archived in the SEATS time-series database of the Ocean Data Bank (ODB) at the National Center for Ocean Research (NCOR). Interested readers may contact NCOR-ODB for data requests. Discrete water samples at depths of 5,10,20,40,60, 80, 100,125, 150, and $200 \mathrm{~m}$ were sampled and transferred into 250-ml BOD bottles from Go-Flo bottles mounted onto a Rosette sampling assembly (General Oceanic Inc.). All water samples are poisoned with $50 \mu \mathrm{l}$ saturated $\mathrm{HgCl}_{2}$ solution immediately after sampling and stored at $5^{\circ} \mathrm{C}$ in darkness to prevent biological alteration (DOE 1994).

Determinations of $\mathrm{TCO}_{2}$ and TA follow the standard operating procedures described in DOE (1994). For $\mathrm{TCO}_{2}$ analysis, a single operator multiparameter metabolic analyzer (SOMMA) system was used to control the pipetting system and extraction of $\mathrm{CO}_{2}$ from seawater samples. The $\mathrm{CO}_{2}$ gas was then measured by a coulometric detector (UIC, Coulometric Inc., model 5011) (Johnson et al. 1993). TA was determined by the potentiometric titration method (Bradshaw et al. 1981; Millero et al. 1993; DOE 1994). The set-up of the titration system is composed of a Radiometer pH meter (pHM-85), a GK 2041C combination electrode, an autoburette (Metrohm 665 Dosimat), an open titration cell, and a temperature-controlled water bath at $25 \pm 0.05^{\circ} \mathrm{C}$. A specific amount of seawater $(\sim 150 \mathrm{~g})$ was first dispensed into the cell, and then titrated with hydrochloric acid, which was prepared in a $\mathrm{NaCl}$ solution with an ionic strength similar to that of seawater of 0.68 , by passing the carbonic acid endpoint. The concentration of acid titrant $(\sim 0.1 \mathrm{~N})$ was calibrated against solutions of $\mathrm{Na}_{2} \mathrm{CO}_{3}$, and then verified by both internal (i.e., seawater samples at a depth of $2500 \mathrm{~m}$ at SEATS) and international (provided by A. G. Dickson of the Scripps Institution of Oceanography) TA reference materials. Titration data passing the carbonic acid endpoint $(\sim 4.5 \mathrm{pH})$ were used to calculate TA, using a proton condition to define TA (Dickson 1981; 1992; Butler 1992). TCO ${ }_{2}$ and TA were normalized to a salinity of 35 in order to eliminate the evaporation/precipitation effect, and are denoted as $\mathrm{NTCO}_{2}$ and NTA, respectively.

Seawater references (batch number \#51) prepared and provided by A. G. Dickson are used throughout this study for assessing the accuracy of our $\mathrm{TCO}_{2}$ and TA measurements. Differences between the certified values $\left(2050.28 \pm 0.03\right.$ and $2269.86 \pm 0.78 \mu \mathrm{mol} \mathrm{kg}^{-1}$ for $\mathrm{TCO}_{2}$ and TA respectively) and our measurements are less than $2 \mu \mathrm{mol} \mathrm{kg}{ }^{-1}$ and $3 \mu \mathrm{mol} \mathrm{kg}^{-1}$ for $\mathrm{TCO}_{2}$ and TA, respectively. Precisions of the $\mathrm{TCO}_{2}$ and TA analyses, estimated by repeated measurements of deep-water samples from $2000-3000 \mathrm{~m}$ on each cruise, are better than $\pm 2 \mu \mathrm{mol} \mathrm{kg}$ and $\pm 2.5 \mu \mathrm{mol} \mathrm{kg}{ }^{-1}$, respectively. Finally, the fugacity of $\mathrm{CO}_{2}\left(\mathrm{fCO}_{2}\right)$ is computed from temperature, salinity, $\mathrm{TCO}_{2}$, TA, phosphate, and silicate data for samples collected from each cruise using the program of Lewis and Wallace (1998), in which the carbonic dissociation constants are adopted from Mehrbach et al. (1973) and refitted by Dickson 
and Millero (1987). It is worth mentioning, however, that phosphate and silicate are almost undetectable at the micro-molar level in the mixed-layer at SEATS site. The error of the calculated $\mathrm{fCO}_{2}$ is less than $\pm 5 \mu$ atm.

\subsection{Correction for Temperature Effect on $\mathrm{fCO}_{2}$}

In this study, the extent of temperature effect is assessed using the equation of Takahashi et al. (2002):

$$
\mathrm{fCO}_{2} \text { at } \mathrm{T}_{\text {obs }}=\left(\text { Mean annual } \mathrm{fCO}_{2}\right) \times \exp \left[0.0423\left(\mathrm{~T}_{\text {obs }}-\mathrm{T}_{\text {mean }}\right)\right] \text {, }
$$

where $\mathrm{T}$ is temperature in ${ }^{\circ} \mathrm{C}$, and the subscripts "mean" and "obs" stand for the annual average and observed values, respectively. In our calculations, we use the averaged values of $\mathrm{fCO}_{2}(364 \mu \mathrm{atm})$ and temperature $\left(27^{\circ} \mathrm{C}\right)$ measured throughout the period of this study as the mean. The resultant $\mathrm{fCO}_{2}$, designated as " $\mathrm{fCO}_{2 \text { mean }}$ corrected for $\Delta \mathrm{T}$ ", are the expected $\mathrm{fCO}_{2}$ values that are only affected by temperature if a parcel of water with a $\mathrm{fCO}_{2}$ value of $364 \mu \mathrm{atm}$ are subjected to seasonal temperature changes (the difference between observed and annual mean temperature) under constant TA and $\mathrm{TCO}_{2}$. Moreover, in order to further discern other factors besides temperature that may affect $\mathrm{fCO}_{2}$ changes, we normalized the observed $\mathrm{fCO}_{2}$ to a constant temperature using the following equation (Takahashi et al. 2002):

$$
\mathrm{fCO}_{2} \text { at } \mathrm{T}_{\text {mean }}=\left(\mathrm{fCO}_{2}\right)_{\text {obs }} \times \exp \left[0.0423\left(\mathrm{~T}_{\text {mean }}-\mathrm{T}_{\text {obs }}\right)\right] \text {, }
$$

where T and the subscripts "mean" and "obs" are defined as the same as those in Eq. (1).

\subsection{Calculation of $\Delta \mathrm{fCO}_{2}$ and Air-sea $\mathrm{CO}_{2}$ Exchange Flux}

Since there are no direct measurements of atmospheric $\mathrm{fCO}_{2}$ at SEATS, we adopted $361.7 \mu \mathrm{atm}$ as the atmospheric $\mathrm{fCO}_{2}$ in our calculations. The value is modified from the average value of 370.89 ppmv reported at Mauna Loa Observatory for 2001 (Keeling and Whorf 2002) after corrections for the equilibrium water vapor pressure at a temperature of $27^{\circ} \mathrm{C}$ and a salinity of 33.5 (i.e., the annual mean temperature and salinity of the surface water at SEATS). Values of $\Delta \mathrm{fCO}_{2}$ in different seasons are derived as follows: spring value is the mean $\Delta \mathrm{fCO}_{2}$ of the observed data in March 2002 and 2003 as well as April 2003; summer value is the observed $\Delta \mathrm{fCO}_{2}$ in July 2002; fall value is the average of $\Delta \mathrm{fCO}_{2}$ in September and November 2002; winter value is the observed $\Delta \mathrm{fCO}_{2}$ in January 2003. The net sea-to-air $\mathrm{CO}_{2}$ flux, $\mathrm{F}$, is then computed using the following equation:

$$
\mathrm{F}=\mathrm{K} \times\left(\Delta \mathrm{fCO}_{2}\right)
$$

where $\mathrm{K}$ is the $\mathrm{CO}_{2}$ gas exchange coefficient, and $\Delta \mathrm{fCO}_{2}$ is $\mathrm{fCO}_{2 \text { (seawater) }}-\mathrm{fCO}_{2 \text { (atmosphere) }}$. The seasonal wind-speed data at a 10-m height are computed from monthly average values for 
1985-1999 from the ECMWF database (Liang et al. 2000). The potential errors in this calculation stem mainly from the uncertainties of the relationship between $\mathrm{K}$ and wind speed, as well as the calculated $\mathrm{fCO}_{2 \text { (seawater), }}$ which includes both analytical errors in $\mathrm{TA}$ and $\mathrm{TCO}_{2}$, and the uncertainties of thermodynamic data applied in the calculation of $\mathrm{fCO}_{2 \text { (seawater) }}$. Therefore, we have used three formulations of K (i.e., Liss and Merlivat 1986; Tans et al. 1990; and Wannikohf 1992), and given an error of $\pm 5 \mu \mathrm{atm}$ to the calculated $\mathrm{fCO}_{2 \text { (seawater) }}$ in order to evaluate uncertainties of the estimated $\mathrm{CO}_{2}$ flux.

\section{RESULTS AND DISCUSSION}

\subsection{The Seasonal Hydrography at the SEATS Site}

The relationships between potential temperature and salinity from different cruises at the SEATS site are depicted in Fig. 2. They are consistent with the general features reported previously for South China Sea waters (Gong et al. 1992; Chen and Huang 1996; Shaw et al. 1996; Lin et al. 1999; Chen et al. 2001; Wong et al. 2002), and have been used frequently to distinguish them from other water masses (e.g., the Western Philippine Sea water) upon mixing. As shown in Fig. 2, the SCS waters are characteristic of both a distinct shallow salinity maximum $\left(\mathrm{S}>34.6 ; \sigma_{\theta}=\sim 24.5\right.$ ) at approximately $150 \mathrm{~m}$ and a pronounced minimum $(\mathrm{S}=\sim 34.4$; $\left.\sigma_{\theta}=\sim 26.8\right)$ at about $350 \mathrm{~m}$. The former is indicative of the North Pacific Tropical Water, while the later fingerprints the core of the North Pacific Intermediate Water (Nitani 1972). Below $15^{\circ} \mathrm{C}$ (which corresponds to a depth of about $200 \mathrm{~m}$ ), data from the seven cruises are indistinguishable from each other throughout the year. On a closer examination, Fig. 2 further shows that sea surface temperature was moderately high $\left(\sim 26^{\circ} \mathrm{C}\right)$ in March 2002 , increased gradually to a maximum of $\sim 30^{\circ} \mathrm{C}$ in July 2002 , then decreased to a minimum of $\sim 24^{\circ} \mathrm{C}$ in January 2003, and rebounded back to $\sim 28^{\circ} \mathrm{C}$ in April 2003, giving a total range of $\sim 6^{\circ} \mathrm{C}$ over the annual cycle. In the meantime, salinities fluctuated between 33.4 and 33.7 with higher values in summer and winter and lower values in spring and fall. Thus, the seasonal variability of temperature and salinity at the SEATS site appears to be confined within the upper $200 \mathrm{~m}$ of the water column and characterized by the summer heating and winter cooling.

\subsection{The Seasonal Patterns of $\mathrm{TCO}_{2} / \mathrm{NTCO}_{2}, \mathrm{TA} / \mathrm{NTA}$ and $\mathrm{fCO}_{2}$ in the Mixed-layer}

In this study, depths of mixed-layer and the data of $\mathrm{TCO}_{2} / \mathrm{NTCO}_{2}$, TA/NTA, and the calculated- $\mathrm{fCO}_{2}$ collected within the mixed-layer from each cruise are averaged to depict their overall seasonality in the mixed-layer at the SEATS site (Fig. 3). As seen in Fig. 3a, the mixed-layer depth, defined as " $\left(\sigma_{\theta}\right.$ at the bottom of mixed-layer $-\sigma_{\theta}$ at $\left.10 \mathrm{~m}\right)=0.1 \mathrm{~kg} \mathrm{~m}^{-3}$ ", remains relatively constant between 20 - $30 \mathrm{~m}$ until late fall (November), then reaches the maximal depth of $\sim 90 \mathrm{~m}$ in January. The deepening of mixed-layer from late fall to winter is caused by the vigorous vertical mixing induced by winter cooling and increased wind stress as a much stronger northeast (winter) monsoon prevails in the SCS during this season (Liu et al. 2002; Tseng et al. 2005). A similar monsoon-induced temperature forcing and convective 


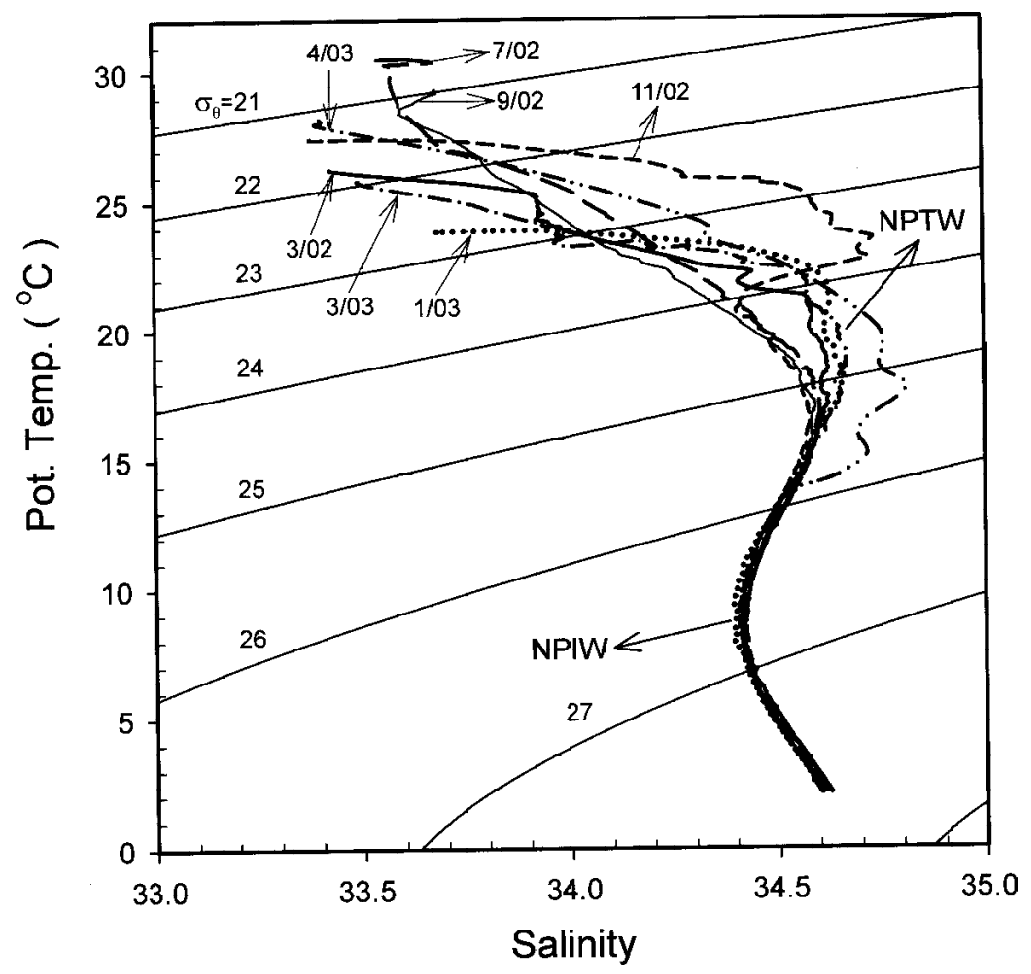

Fig. 2. T-S diagram showing the distinct shallow salinity maximum $(\mathrm{S}>34.6$; $\left.\sigma_{\theta}=\sim 24.5\right)$ at approximately $150 \mathrm{~m}$ and the pronounced salinity minimum ( $\mathrm{S}>34.4 ; \sigma_{\theta}=\sim 26.8$ ) at about $350 \mathrm{~m}$, a typical feature of the South China Sea waters. (NPTW: North Pacific Tropical Water; NPIW: North Pacific Intermediate Water)

mixing during northeast monsoon and inter-monsoon seasons are also observed in the central Arabian Sea (Goyet et al. 1998; Sarma et al. 1998; 2000).

$\mathrm{TCO}_{2}$ remains fairly constant from $\sim 1887$ to $\sim 1898 \mu \mathrm{mol} \mathrm{kg}^{-1}$ throughout the period of this study except for the highest value of $\sim 1925 \mu \mathrm{mol} \mathrm{kg}{ }^{-1}$ in winter (Fig. 3b). The $\mathrm{TCO}_{2}$ maximum thus coincides with the deepening of the mixed-layer (Fig. 3a) and the winter cooling. Such a close association suggests that the strong northeast monsoon not only causes vigorous downward mixing to deepen the mixed-layer but also brings in more cold, $\mathrm{TCO}_{2}$-rich subsurface waters from the deep. The drawdown of $\mathrm{NTCO}_{2}$ in spring-summer (Fig. 3c) manifests the biological uptake in the mixed-layer. Similar observations were also reported previously at time-series stations of BATS (Bates et al. 1996) and HOT (Winn et al. 1994).

Figure $3 \mathrm{~d}$ shows the seasonal variability of TA measured in the mixed-layer at SEATS site. TA values vary from $\sim 2190$ to $\sim 2220 \mu \mathrm{mol} \mathrm{kg}{ }^{-1}$ with higher values in January, July and September and lower values in March, April and November. The observed seasonal oscilla- 

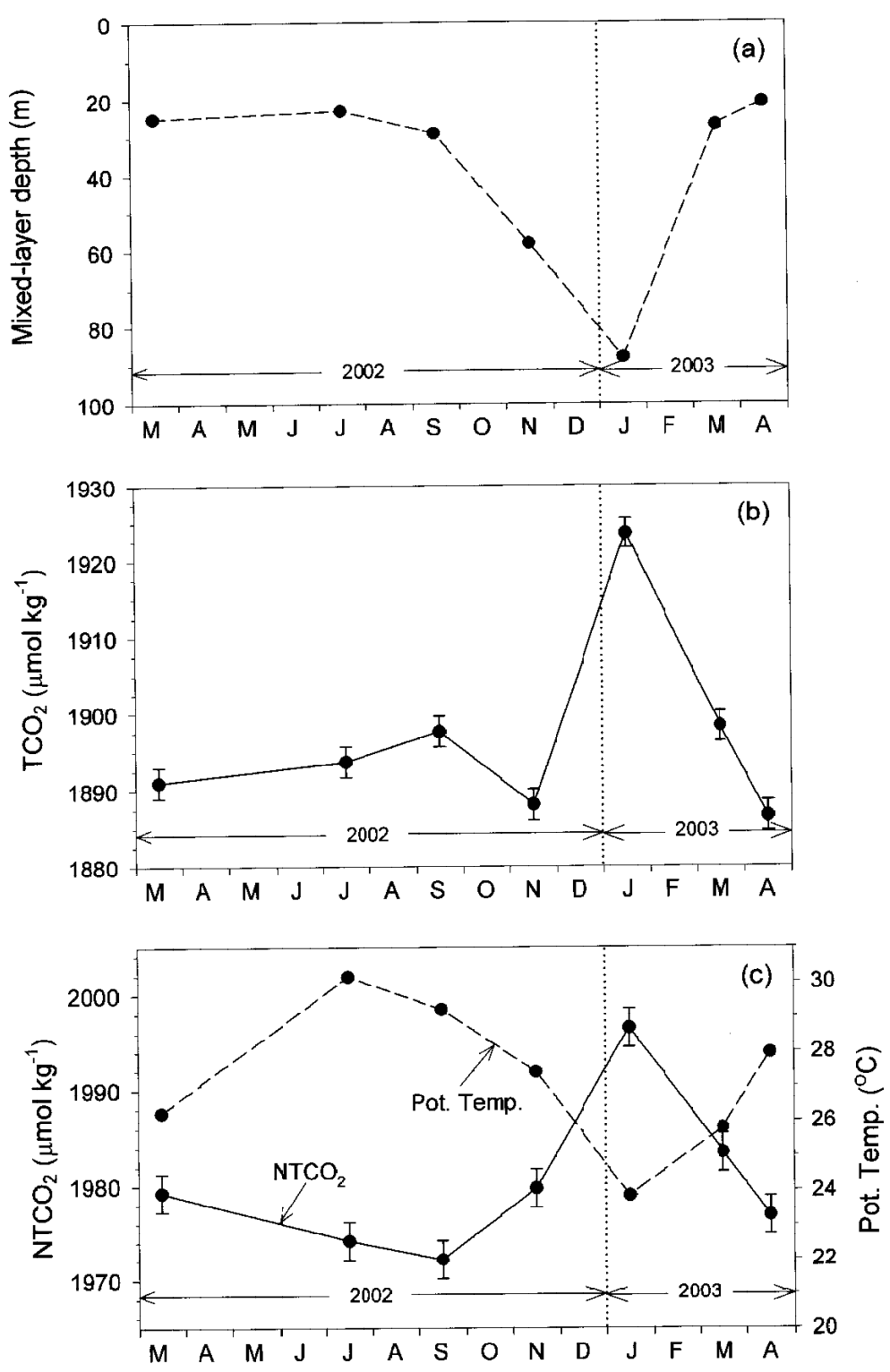

Fig. 3. Seasonal fluctuations of (a) the mixed-layer depth, (b) $\mathrm{TCO}_{2}$, (c) $\mathrm{NTCO}_{2}$ (solid line) and potential temperature (dash line), (d) TA (solid line) and salinity (dash line), (e) NTA and (f) $\mathrm{fCO}_{2}$ (solid line) and potential temperature (dash line) in the mixed-layer at the SEATS site from March 2002 to April 2003. The data points represent the averaged values of all samples measured in the mixed-layer from each cruise. The vertical bars indicate the analytical errors $( \pm 1 \sigma)$. 

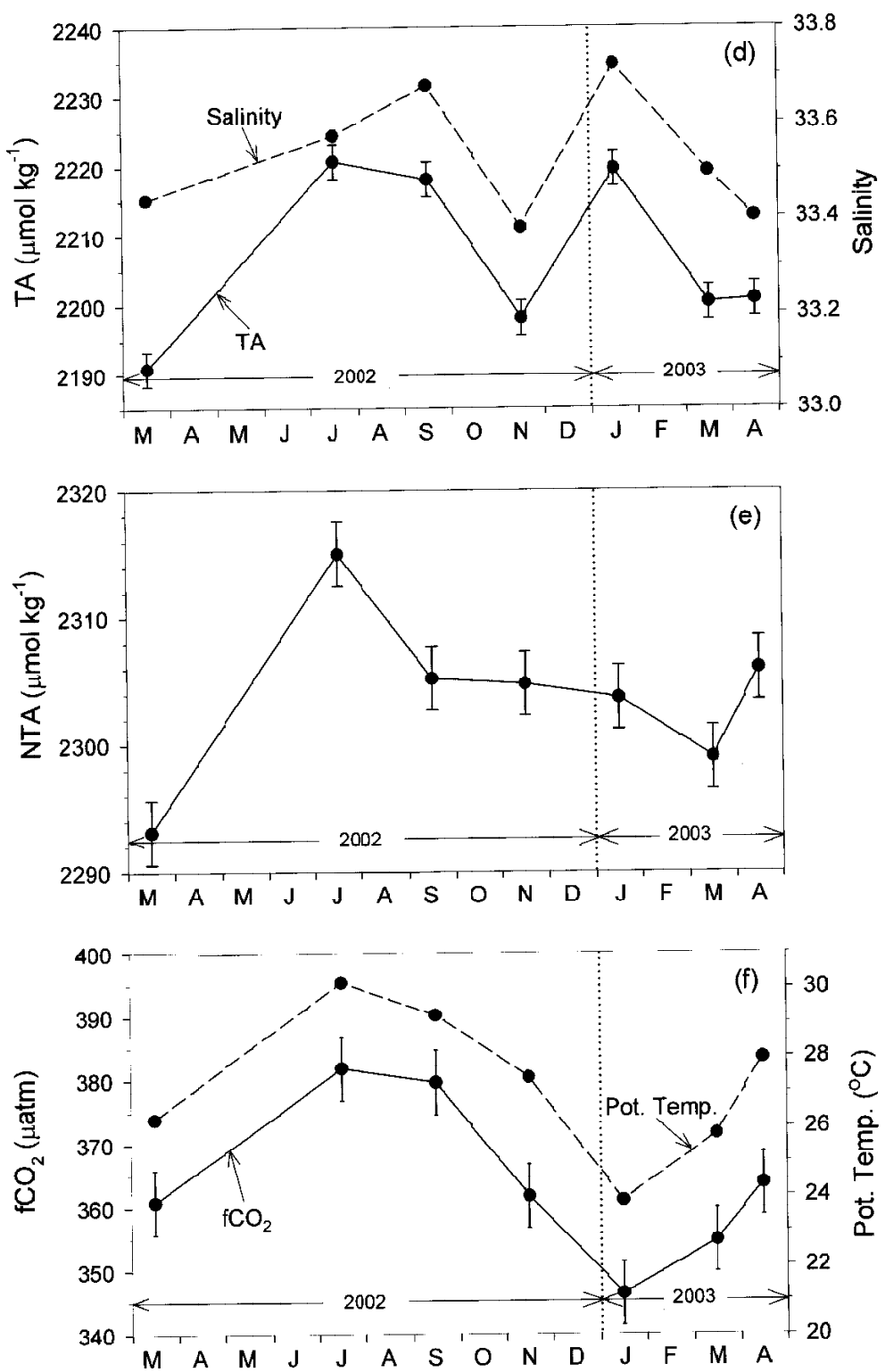

Fig. 3. Continued.

tion of TA is thus controlled primarily by the same factors affecting salinity. A similar relationship between TA and salinity is also documented at BATS and HOT sites (Winn et al. 1994; Bates et al. 1996). However, as revealed in Fig. 3e, NTA remains variable throughout the year, suggesting the potential contribution of the formation and/or dissolution of $\mathrm{CaCO}_{3}$ and the consumption and/or remineralization of nitrate to the observed NTA variability. 
A strong seasonality with an amplitude of $\sim 35 \mu$ atm during the annual cycle is found in the mixed-layer $\mathrm{fCO}_{2}$ at the SEATS site (Fig. 3f). The $\mathrm{fCO}_{2}$ increases progressively in spring to summer with the maximum in July ( 382 $\mu \mathrm{atm})$ followed by a decrease in fall to winter with the minimum ( $347 \mu \mathrm{atm})$ in January. The seasonal changes of $\mathrm{fCO}_{2}$ are closely in phase with temperature (Fig. 3f) but are inversely correlated with $\mathrm{NTCO}_{2}$ (Fig. 3c). These relationships suggest that the variation in $\mathrm{fCO}_{2}$ at SEATS is controlled ultimately by seawater temperature change, and will be examined in detail in the following sections.

\subsection{Processes Controlling the Mixed-layer $\mathrm{fCO}_{2}$ at the SEATS Site}

Figure 4 depicts graphically the seasonal variability of " $\mathrm{fCO}_{2 \text { mean }}$ corrected for $\Delta \mathrm{T}$ ", the observed $\mathrm{fCO}_{2}$, and " $\mathrm{fCO}_{2}$ at $27^{\circ} \mathrm{C}$ " at the SEATS site. As can be seen, the magnitude of seasonal variation of the " $\mathrm{fCO}_{2 \text { mean }}$ corrected for $\Delta \mathrm{T}$ " is greater than the observed seasonal $\mathrm{fCO}_{2}$ fluctuation, and the " $\mathrm{fCO}_{2}$ at $27^{\circ} \mathrm{C}$ " and the " $\mathrm{fCO}_{2 \text { mean }}$ corrected for $\Delta \mathrm{T}$ " are inversely correlated. These relationships imply that the temperature effect on the seasonal variability of $\mathrm{fCO}_{2}$ must have been compensated in part by other factors to yield the observed smaller amplitude.

These factors other than temperature include biological processes, air-sea exchanges of $\mathrm{CO}_{2}$ and vertical transport of subsurface waters. Although it is difficult to discern their respective effects on the seasonal $\mathrm{fCO}_{2}$ oscillations, the decrease in " $\mathrm{fCO}_{2}$ at $27^{\circ} \mathrm{C}$ " from winter to summer (the warming period) can be attributed chiefly to biological effects because both the upward transport of subsurface waters and the air-sea $\mathrm{CO}_{2}$ exchange are minimal during this period of time. The shoaling of the mixed-layer during the warming period (Fig. 3a) results in a stronger stratification that, in turn, prevents subsurface waters underneath the mixedlayer from moving upward. To further estimate the extent of biological effects on the mixedlayer $\mathrm{fCO}_{2}$, we will use the " $\mathrm{fCO}_{2}$ at $27^{\circ} \mathrm{C}$ " in January 2003 and July 2002 as winter and summer values, respectively, in the following discussion. Accordingly, the decline of " $\mathrm{fCO}_{2}$ at $27^{\circ} \mathrm{C}$ " from winter to summer is $\sim 60 \mu \mathrm{atm}$ (Fig. 4), yet the drawdown of $\mathrm{TCO}_{2}$ is only about one-half of that figure $\left(\sim 30 \mu \mathrm{mol} \mathrm{kg}{ }^{-1}\right.$; Fig. 3c). Using a Revelle factor of 10 (Takahashi et al. 1993), the observed drop in $\mathrm{TCO}_{2}$ is calculated to be equivalent to a decrease of $\mathrm{fCO}_{2}$ of $\sim 55 \mu \mathrm{atm}$. The close agreement between the measured difference and the hypothetical value (60 vs. $55 \mu \mathrm{atm}$ ) thus confirms the aforementioned biological utilization responsible for the decrease of " $\mathrm{fCO}_{2}$ at $27^{\circ} \mathrm{C}$ " during the warming period.

On the other hand, the increase of " $\mathrm{fCO}_{2}$ at $27^{\circ} \mathrm{C}$ " from summer to winter (the cooling period) mainly results from the entrainment of subsurface water from the deep. Assuming the biological effect is the same as that of the warming period (i.e., -60 $\mu \mathrm{atm}$ ) and the effect of air-sea exchange is negligible on the $\mathrm{fCO}_{2}$ variation during the cooling period, a simple massbalance calculation shows that the entrainment of the subsurface water will lead to an increase of $\mathrm{fCO}_{2}$ of $+120 \mu \mathrm{atm}$ in the mixed-layer during this period, providing that the temperature effect on the $\mathrm{fCO}_{2}$ change is about $-90 \mu \mathrm{atm}$ (i.e., the difference of " $\mathrm{fCO}_{2 \text { mean }}$ corrected for $\Delta T$ " between July 2002 and January 2003; Fig. 4) and the observed $\mathrm{fCO}_{2}$ change is about $-30 \mu \mathrm{atm}$. 


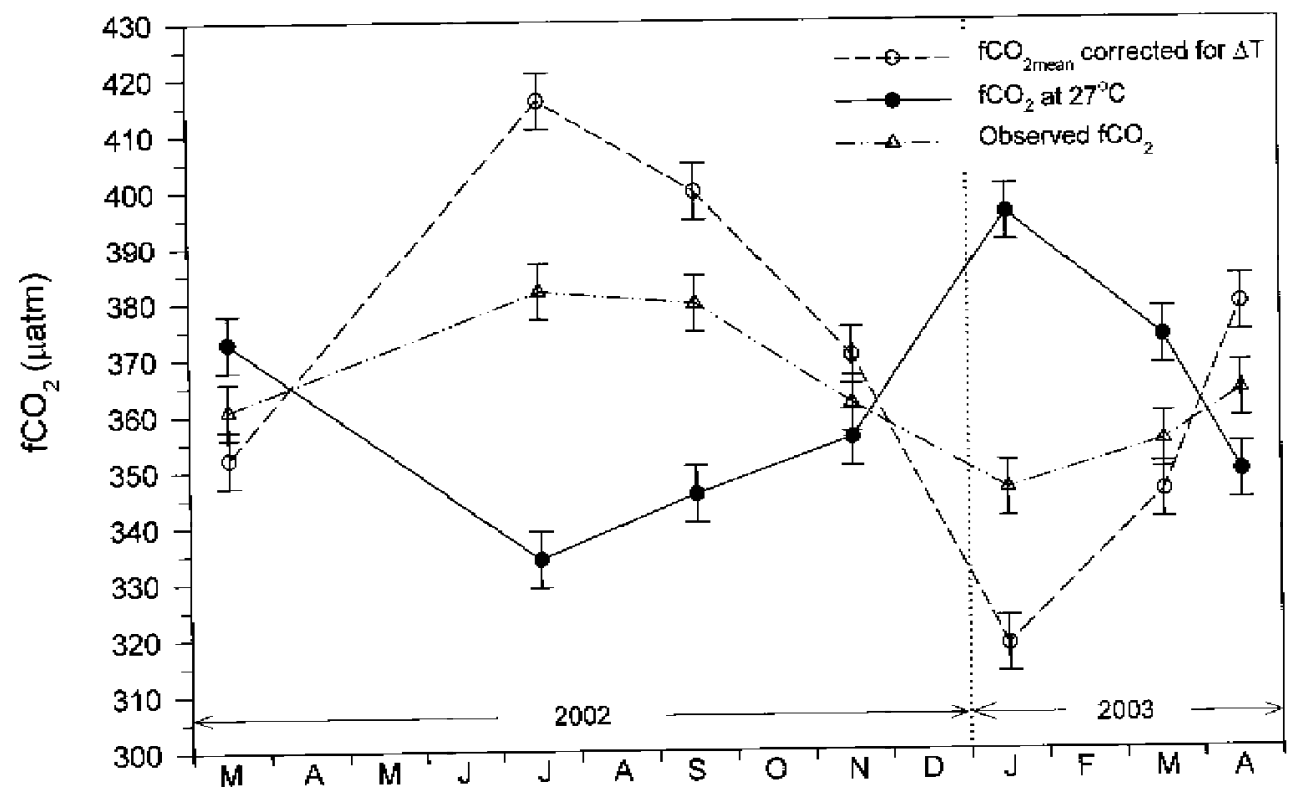

Fig. 4. Seasonal variability of " $\mathrm{fCO}_{2 \text { mean }}$ corrected for $\Delta \mathrm{T}$ " (open circle), " $\mathrm{fCO}_{2}$ at $27^{\circ} \mathrm{C}$ " (filled circle), and observed $\mathrm{fCO}_{2}$ (open triangle) in the mixed layer at the SEATS site from March 2002 to April 2003. The vertical bars represent the range of potential errors. (see text for details in the definitions and calculations of " $\mathrm{fCO}_{2 \text { mean }}$ corrected for $\Delta \mathrm{T}$ " and " $\mathrm{fCO}_{2}$ at $27^{\circ} \mathrm{C} "$ )

\subsection{Assessing the Relative Importance of the Biological and Temperature Effects on}

\section{Seasonal $\mathrm{fCO}_{2}$ Variability at the SEATS Site}

The relative importance of the temperature and biological effects on surface-water $\mathrm{fCO}_{2}$ can be evaluated in terms of (T/B) and/or (T-B), in which (T/B) $=\left[\left(\Delta \mathrm{fCO}_{2}\right)_{\text {temp }} /\left(\Delta \mathrm{fCO}_{2}\right)_{\text {bio }}\right]$ and/or $(\mathrm{T}-\mathrm{B})=\left[\left(\Delta \mathrm{fCO}_{2}\right)_{\text {temp }}-\left(\Delta \mathrm{fCO}_{2}\right)_{\text {bio }}\right]$ (Takahashi et al. 2002). According to the authors, the biological effect, $\left(\Delta \mathrm{fCO}_{2}\right)_{\text {bio }}$, on the surface-water $\mathrm{fCO}_{2}$ can be represented by the seasonal amplitude of " $\mathrm{fCO}_{2}$ at $\mathrm{T}_{\text {mean }}$ ", i.e., $\left(\Delta \mathrm{fCO}_{2}\right)_{\text {bio }}=\left(\mathrm{fCO}_{2 \text { mean }} \text { at } \mathrm{T}_{\text {mean }}\right)_{\text {max }}-\left(\mathrm{fCO}_{2 \text { mean }} \text { at } \mathrm{T}_{\text {mean }}\right)_{\text {min }}$, while the temperature effect, $\left(\Delta \mathrm{fCO}_{2}\right)_{\text {temp }}$, can be estimated from the seasonal magnitude of the " $\mathrm{fCO}_{2 \text { mean }}$ corrected for $\Delta \mathrm{T}$ ", i.e., $\left(\Delta \mathrm{fCO}_{2}\right)_{\text {temp }}=\left(\mathrm{fCO}_{2 \text { mean }} \text { corrected for } \Delta \mathrm{T}\right)_{\max }-\left(\mathrm{fCO}_{2 \text { mean }}\right.$ corrected for $\Delta \mathrm{T})_{\min }$. In any given oceanic regime, if the effect of temperature exceeds the biological effect, the $(\mathrm{T} / \mathrm{B})$ ratio is greater than 1 and the $(\mathrm{T}-\mathrm{B})$ is positive, whereas in areas where the biological effect appears to surpass the temperature effect, the $(\mathrm{T} / \mathrm{B})$ ratio varies from 0 to 1 , and the (T-B) is negative. In areas where the two effects are equally important and cancel each other out, the (T/B) ratio is 1 and $(\mathrm{T}-\mathrm{B})$ is 0 . 
Figure 4 shows that the maximum and minimum of " $\mathrm{fCO}_{2}$ at $27^{\circ} \mathrm{C}$ " at the SEATS site are $\sim 395$ and $\sim 333 \mu \mathrm{atm}$, respectively, while the maximum and minimum of the " $\mathrm{fCO}_{2 \text { mean }}$ corrected for $\Delta \mathrm{T}$ " are $\sim 415$ and $\sim 318 \mu \mathrm{atm}$. The maximal changes of $\left(\Delta \mathrm{fCO}_{2}\right)_{\text {bio }}$ and $\left(\Delta \mathrm{fCO}_{2}\right)_{\text {temp }}$, therefore, are $\sim 62 \mu \mathrm{atm}$ and $\sim 97 \mu \mathrm{atm}$, respectively. Accordingly, the (T/B) ratio and the (TB) difference are calculated to be 1.6 and $35 \mu \mathrm{atm}$, respectively. The results thus indicate that temperature overwhelms the biological effect on regulating the mixed-layer $\mathrm{fCO}_{2}$ at the SEATS site.

A comparison of our results with those from other time-series stations (e.g., HOT, BATS, KNOT and OSP) is shown in Table 1. It is evident that the effect of temperature surpasses the biological effect at all of the subtropical time-series stations (SEATS, HOT and BATS), while the opposite is evident for stations located at high latitudes (KNOT and OSP). The contrast is attributed to the fact that the nutrient-rich surface waters in high latitudes usually are high in biological production and tend to reinforce the biological effect on regulating the $\mathrm{fCO}_{2}$ in the mixed-layer. It should be noted that both temperature ( 97 vs. $59 \mu \mathrm{atm}$ ) and biological (62 vs. $23 \mu \mathrm{atm}$ ) effects on the $\mathrm{fCO}_{2}$ in the mixed-layer at the SEATS site are greater than those at

Table 1. Comparison of the relative importance of temperature and biological effects on $\mathrm{fCO}_{2}$ variations at the SEATS site with those at HOT, BATS, KNOT and OSP time-series stations.

\begin{tabular}{|c|c|c|c|c|}
\hline & $\begin{array}{l}\text { Location and } \\
\text { Oceanic regime } \\
\text { represented }\end{array}$ & $\begin{array}{c}\text { Temperature effect } / \\
\text { Biological effect }\end{array}$ & $\begin{array}{l}\text { Temperature effect - } \\
\text { Biological effect }\end{array}$ & References \\
\hline SEATS & $\begin{array}{c}18^{\circ} 15^{\prime} \mathrm{N}, 115^{\circ} 35^{\circ} \mathrm{E} \\
\text { South China Sea, the } \\
\text { largest subtropical } \\
\text { marginal sea }\end{array}$ & $1.6(97 / 62 \mu \mathrm{atm})$ & $+35 \mu \operatorname{tam}$ & This study \\
\hline HOT & $\begin{array}{l}22^{\circ} 45^{\prime} \mathrm{N}, 158^{\circ} \mathrm{W} \\
\text { North Pacific } \\
\text { subtropical gyre }\end{array}$ & $2.6(59 / 23 \mu \mathrm{atm})$ & $+36 \mu \operatorname{tam}$ & $\begin{array}{l}\text { Calculated based on } \\
\text { Winn et al. (1994) }\end{array}$ \\
\hline BATS & $\begin{array}{c}31^{\circ} 50^{\prime} \mathrm{N}, 64^{\circ} 10^{\circ} \mathrm{W} \\
\text { Western North Atlantic } \\
\text { subtropical gyre }\end{array}$ & $2.7(150 / 55 \mu \mathrm{atm})$ & $+95 \mu \operatorname{tam}$ & $\begin{array}{c}\text { Bates et al. (2001) } \\
\text { Takahashi et al. (2002) }\end{array}$ \\
\hline KNOT & $\begin{array}{c}44^{\circ} \mathrm{N}, 155^{\circ} \mathrm{E} \\
\text { Northwestern subarctic } \\
\text { Pacific Ocean }\end{array}$ & $0.8(174 / 228 \mu \mathrm{atm})$ & $-54 \mu \mathrm{tam}$ & $\begin{array}{l}\text { Calculated based on } \\
\text { Tsurushima et al. (2002) }\end{array}$ \\
\hline OSP & $\begin{array}{c}50^{\circ} \mathrm{N}, 145^{\circ} \mathrm{W} \\
\text { Northeastern subarctic } \\
\text { Pacific Ocean }\end{array}$ & $0.9(100 / 115 \mu \mathrm{atm})$ & $-10 \mu \mathrm{tam}$ & $\begin{array}{l}\text { Wong and Chan (1991) } \\
\text { Takahashi et al. (2002) }\end{array}$ \\
\hline
\end{tabular}


HOT, despite the fact that both sites are situated at similar latitudes in the oligotrophic oceanic regime and have a similar seasonal change in mixed-layer depth (Neuer et al. 2002). The discrepancy thus can be attributed to the shallower thermocline, nutricline and $\mathrm{TCO}_{2}$-cline at SEATS than those at HOT (Fig. 5), because the cold, nutrient-laden, $\mathrm{TCO}_{2}$-rich subsurface waters can entrain easily from the deep to result in a greater amplitude of temperature and biological effects on the surface water $\mathrm{fCO}_{2}$.

\subsection{The Seasonal Pattern of $\Delta \mathrm{fCO}_{2}$ and Air-sea Exchange of $\mathrm{CO}_{2}$ at the SEATS Site}

Figure 6 shows the seasonal variability of $\Delta \mathrm{fCO}_{2}$ at the SEATS site, in which the maximum positive and negative $\Delta \mathrm{fCO}_{2}$ occur in summer $(\sim+20 \mu \mathrm{atm}$; July 2002) and in winter ( -15 $\mu$ atm; January 2003), respectively. In other words, there has been an efflux of $\mathrm{CO}_{2}$ from the SCS in summer and fall but an influx of $\mathrm{CO}_{2}$ into the surface SCS in winter. The seasonal variability also reveals that the $\Delta \mathrm{fCO}_{2}$ increases gradually from spring to summer, and then decreases progressively from fall to winter. Values of the calculated sea-to-air $\mathrm{CO}_{2}$ flux at the SEATS site using different formulations (see Methods) are listed in Table 2. As seen, they vary remarkably in different seasons and depend on which formula is used in calculations, ranging from $0.00 \pm 0.01$ to $-0.02 \pm 0.05$ (spring), $+0.03 \pm 0.01$ to $+0.23 \pm 0.06$
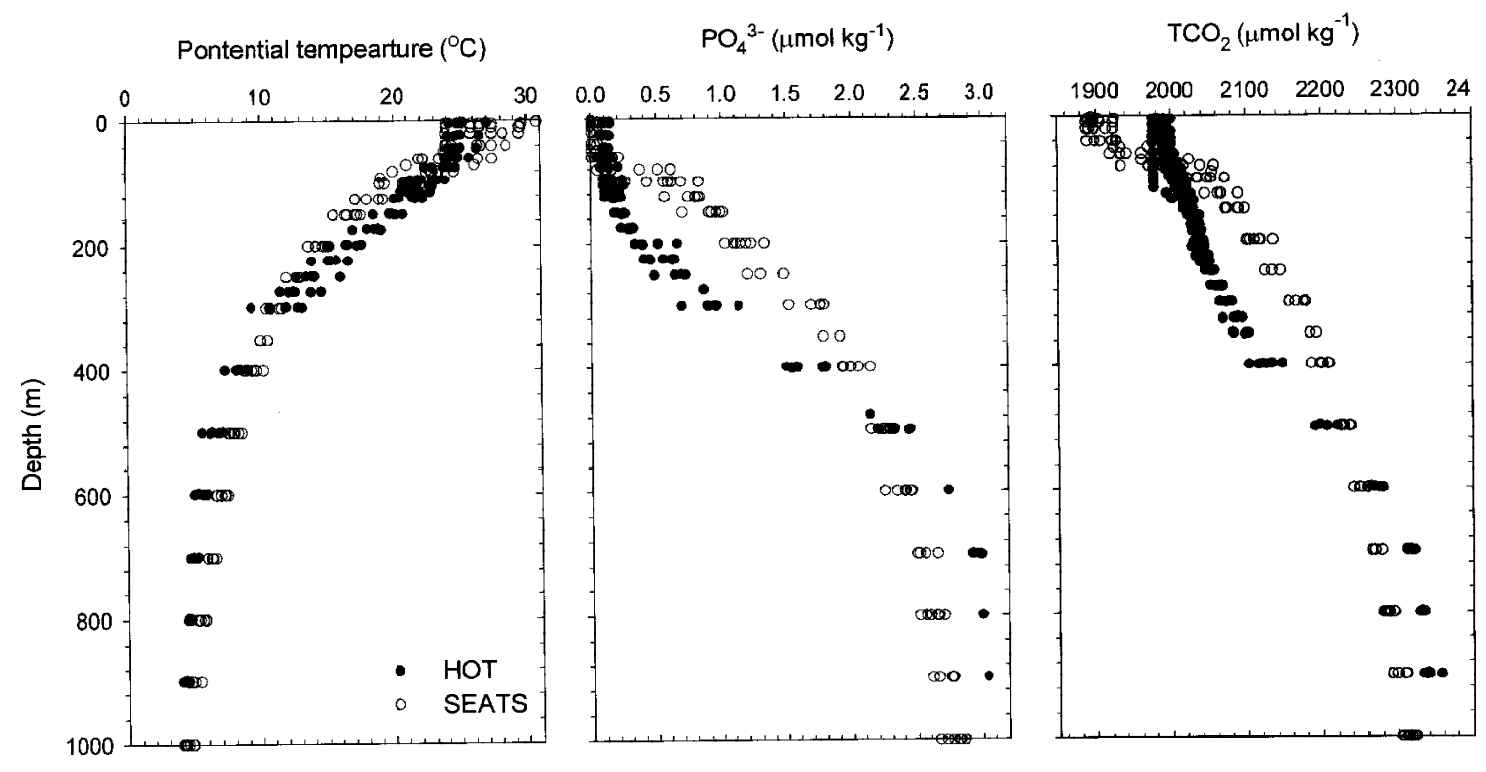

Fig. 5. Comparison of depth distributions of potential temperature, $\mathrm{PO}_{4}{ }^{-3}$, and $\mathrm{TCO}_{2}$ from surface to $1000 \mathrm{~m}$ between the SEATS and HOT sites. The profiles of HOT are plotted from data collected in June, July, August, and December 1998, as well as January and February 1999 (R. Lukas and D. Karl, HOT project, 1999). 
(summer), $+0.18 \pm 0.10$ to $+0.45 \pm 0.25$ (fall), and $-0.62 \pm 0.20$ to $-1.42 \pm 0.46$ (winter) molC $\mathrm{m}^{-2}$ year $^{-1}$. It further shows that the annual sea-to-air $\mathrm{CO}_{2}$ flux is dominated by the influx of $\mathrm{CO}_{2}$ from the atmosphere onto the surface waters in winter. It is worth pointing out that despite the bigger positive $\Delta \mathrm{fCO}_{2}$ in summer, the modest wind speed results in a rela-

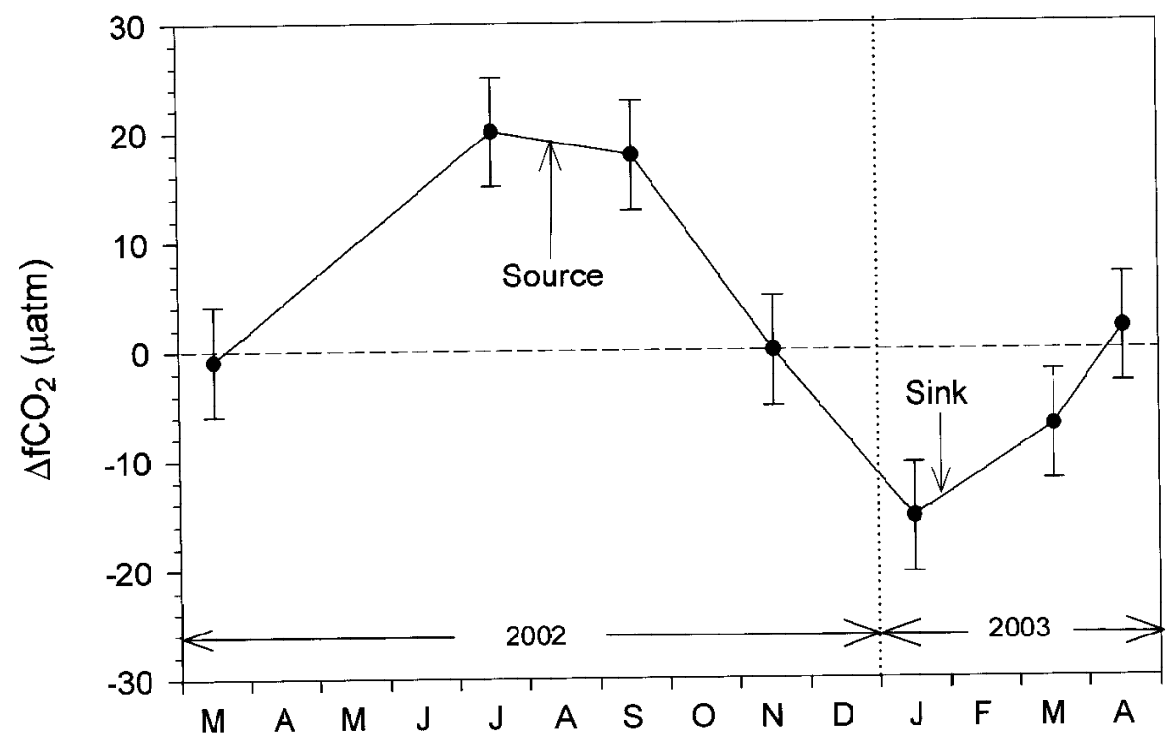

Fig. 6. Seasonal variations of $\Delta \mathrm{fCO}_{2}$ (surface seawater $\mathrm{fCO}_{2}$ - atmospheric $\mathrm{fCO}_{2}$ ) in the mixed layer at SEATS site from March 2002 to April 2003. The vertical bars represent the range of potential errors.

Table 2. Estimates of seasonal $\mathrm{CO}_{2}$ flux at the SEATS site using formulations of Liss and Merlivat (1986), Tans et al. (1990), and Wanninkhof (1992). The seasonal wind speed data are calculated from monthly averaged values for 1985-1999 from the ECMWF database (Liang et al. 2000).

\begin{tabular}{|c|c|c|c|c|c|c|c|c|}
\hline & \multirow{3}{*}{$\begin{array}{l}\triangle \mathrm{fCO}_{2} \\
(\mu \mathrm{atm})\end{array}$} & \multirow{3}{*}{$\begin{array}{l}\text { Wind speed } \\
\left(\mathrm{ms}^{-1}\right)\end{array}$} & \multicolumn{6}{|c|}{ 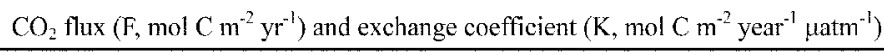 } \\
\hline & & & \multicolumn{2}{|c|}{ Liss and Merlivat (1986) } & \multicolumn{2}{|c|}{ Tans et al. (1990) } & \multicolumn{2}{|c|}{ Wanninkhof $(1992)$} \\
\hline & & & K & $\mathrm{F}$ & K & F & $\mathrm{K}$ & F \\
\hline Spring & $-1.9 \pm 5$ & 3.1 & 0.001 & $0.00 \pm 0.01$ & 0.002 & $0.00 \pm 0.01$ & 0.011 & $-0.02 \pm 0.05$ \\
\hline Summer & $20.1 \pm 5$ & 3.2 & 0.001 & $0.03 \pm 0.01$ & 0.003 & $0.06 \pm 0.02$ & 0.012 & $0.23 \pm 0.06$ \\
\hline Fall & $9.0 \pm 5$ & 6.1 & 0.018 & $0.18 \pm 0.10$ & 0.050 & $0.45 \pm 0.25$ & 0.042 & $0.38 \pm 0.21$ \\
\hline Winter & $-15.3 \pm 5$ & 8.8 & 0.041 & $-0.62 \pm 0.20$ & 0.093 & $-1.42 \pm 0.46$ & 0.087 & $-1.33 \pm 0.43$ \\
\hline Yearly Average & & & & $-0.11 \pm 0.08$ & & $-0.23 \pm 0.18$ & & $-0.19 \pm 0.19$ \\
\hline
\end{tabular}


tively small $\mathrm{CO}_{2}$ efflux. In contrast, the high wind speed in winter gives rise to higher $\mathrm{CO}_{2}$ influx regardless of the smaller $\Delta \mathrm{fCO}_{2}$. The annual sea-to-air $\mathrm{CO}_{2}$ flux at the SEATS site is estimated to be around $-0.11 \pm 0.08$ to $-0.23 \pm 0.18 \mathrm{molC} \mathrm{m}^{-2}$ year $^{-1}$ during the observed period (Table 2), and is in good agreement with that reported previously by Takahashi et al. (2002) in the SCS region ( $\sim 0$ to $-0.4 \mathrm{molC} \mathrm{m}^{-2}$ year $\left.^{-1}\right)$.

Similar seasonal patterns have also been documented at BATS and HOT (Winn et al. 1994; Bates et al. 1996). Our estimates, however, are less than $-0.7 \mathrm{molC} \mathrm{m}^{-2} \mathrm{year}^{-1}$ found at HOT (Winn et al. 1994) or -0.3 to -0.6 molC m$^{-2}$ year $^{-1}$ found at BATS (Bates et al. 1998). The lower values at SEATS can be attributed to the higher sea surface temperature at SEATS, which increases $\mathrm{fCO}_{2}$ in the surface water and depresses the capacity for $\mathrm{CO}_{2}$ uptake, and the general upwelling circulation in the SCS (Chao et al. 1996; Chen et al. 2001). Finally, if the estimated annual sea-to-air $\mathrm{CO}_{2}$ flux at SEATS are extrapolated to the entire SCS $\left(3.5 \times 10^{6} \mathrm{~km}^{2}\right)$, it could take up $4.5 \pm 3.3 \sim 9.6 \pm 7.7 \mathrm{TgC} \mathrm{yr}^{-1}$, i.e., only about $0.20 \pm 0.15$ to $0.44 \pm 0.35 \%$ of the total $\mathrm{CO}_{2}$ uptake by the global oceans $\left(\sim 2.2 \mathrm{PgC} \mathrm{yr}^{-1}\right.$; Takahashi et al. 2002). These values are small, considering the SCS's share that occupies $0.97 \%$ of the total ocean area. The small fraction of $\mathrm{CO}_{2}$ uptake estimated for the SCS in this study, however, is consistent with the small percentage of $\mathrm{CO}_{2}$ inventory reported by Chen et al. (2005), in which the SCS contains $0.6 \pm 0.1 \mathrm{PgC}$ of anthropogenic $\mathrm{CO}_{2}$, while the global ocean inventory is about $100 \mathrm{PgC}$.

\subsection{Estimate of Net Community Production and the "Mysterious Carbon Drawdown"}

In our previous discussion, we attributed the decrease of $\mathrm{NTCO}_{2}$ and the drawdown of " $\mathrm{fCO}_{2}$ at $27^{\circ} \mathrm{C}$ " from winter to summer to the biological uptake. The net amount of $\mathrm{NTCO}_{2}$ consumed biologically in the mixed-layer during this warming period can be regarded as the net community production (NCP), i.e., the difference between primary production and net community respiration. The observed change of $\mathrm{NTCO}_{2}$ between the overturned period in winter (Tseng et al. 2005) and the stratified period in summer is about $25 \mu \mathrm{mol} \mathrm{kg}^{-1}$ (Fig. 3c). Assuming a mean mixed-layer depth of $50 \mathrm{~m}$, the NCP in the mixed-layer can be calculated to be about $1.25 \pm 0.14 \mathrm{molC} \mathrm{m}{ }^{-2}$. Since this value only represents the phytoplankton growth over the first six months in a year, the annual net community production would be about $6.8 \pm$ $0.77 \mathrm{mmolC} \mathrm{m}^{-2} \mathrm{year}^{-1}$, if the NCP during the cooling period, i.e., from summer to winter, were the same as that during the warming period. The source of $\mathrm{TCO}_{2}$ as well as nutrients in the later six months in a year is assumed to be supplied by less dramatic but significant diffusive fluxes, including typhoon mixing (Lin et al. 2003). The uncertainty in this calculation was assumed to derive only from the analytical error of $\mathrm{TCO}_{2}$, which was reported as $\pm 2 \mu \mathrm{mol} \mathrm{kg}^{-1}$. Accordingly, a corresponding error of $\pm 2.8 \mu \mathrm{mol} \mathrm{kg}{ }^{-1}$ in $\Delta \mathrm{NTCO}_{2}$ (the square root of two times of $\mathrm{TCO}_{2}$ 's error) was applied to estimate the uncertainty of calculated NCP.

In a thorough investigation of the roles of nitrogen in modulating phytoplankton growth in the northern SCS basin, Chen et al. (2004) noted a great variability of primary production between 15.0 and $27.5 \mathrm{mmolC} \mathrm{m}^{-2}$ year $^{-1}$ in March 2000 and 2001, respectively, while the new production varied from 5.0 to $10.0 \mathrm{mmolC} \mathrm{m}^{-2}$ year $^{-1}$. In addition, using a modeling result and the data from SeaWiFS ocean color images, Liu et al. (2002) reported an annual 
mean primary productivity of $\sim 23.3-29.5 \mathrm{mmolC} \mathrm{m}^{-2} \mathrm{year}^{-1}$, and predicted an e-ratio of 0.12 in the SCS. In other words, the averaged export production in the SCS would range from 2.80 to $3.54 \mathrm{mmolC} \mathrm{m}^{-2}$ year $^{-1}$. Our estimated NCP using carbon data in this study is thus in reasonable agreement with the reported new and export productions, and supports the importance of biological utilization in controlling the observed seasonal drawdown of " $\mathrm{fCO}_{2}$ at $27^{\circ} \mathrm{C}$ " and $\mathrm{NTCO}_{2}$ from winter to summer at the SEATS site in the South China Sea.

Nonetheless, nitrate concentrations in the mixed-layer at the SEATS site are undetectable except a trace of $0.5 \mu \mathrm{mol} \mathrm{kg}{ }^{-1}$ found in January during the course of this study. The observation of no measurable nitrate in the mixed-layer during spring and summer is also reported by Wong et al. (2002) and Chen et al. (2004). The continuous decrease of $\mathrm{NTCO}_{2}$ in the absence of measurable nitrate, the so-called "mysterious carbon drawdown", observed in this study has also been observed at BATS and HOT time-series stations (Michaels et al. 1994; Bates et al. 1996; Karl et al. 1997). A recent global ocean analysis further shows that such a phenomenon is a common feature for all tropical and subtropical marine habitats (Lee et al. 2001). Moreover, it has been shown that in seawaters of low-nitrate concentrations the $\mathrm{C}: \mathrm{N}$ ratio utilized by marine organisms is very different from the conventional Redfield (Copin-Montegut 2000; Michaels et al. 2001). Assuming a C: N ratio of 16 (ref. Copin-Montégut 2000), the utilization of $0.5 \mu \mathrm{mol} \mathrm{kg}{ }^{-1}$ nitrate can only sustain $8 \mu \mathrm{mol} \mathrm{kg}^{-1}$ of $\mathrm{NTCO}_{2}$ drawdown, i.e., only $32 \%$ of the overall drawdown of $\mathrm{NTCO}_{2}\left(25 \mu \mathrm{mol} \mathrm{kg}{ }^{-1}\right.$; Fig. 3c $)$ measured between winter and summer.

It thus appears that other sources of nitrogen from processes such as nitrogen fixation, riverin inputs, vertical migration of zooplankton, utilization of dissolved organic nitrogen, vertical diffusion of nutrients from the deep, horizontal advection and atmospheric deposition are required to compensate for the deficit. For instance, nitrogen fixation has been the most frequently mentioned process in the literature and shown to be a new production pathway in nutrient-depleted waters (Karl et al. 1997; Michaels et al. 2000). In fact, Wong et al. (2002) report high values of nitrate anomaly up to $2.5 \mu \mathrm{mol} \mathrm{kg}$-1 at the SEATS site from the fall through early spring during the northeast monsoon, indicating that the remineralization of nitrogen-rich organic matter formed by nitrogen fixation have played an important role in nutrient dynamics in the northern SCS. However, as shown by Chen et al. (2004), the nitrogen-fixing cynobacteria, Trichodesmium $\mathrm{sp}$. and $R$. intracellularis, are both sparsely distributed in the mixed layer during spring, and constitute less than $3 \%$ of the new production. The dichotomy between rates of nitrogen fixation measured directly by biological techniques and inferred from geochemical data in the North Atlantic has been thoroughly investigated by Bates and Hansell (2004) and Hansell et al. (2004). Further studies, therefore, are necessary to elucidate the sources of nitrogen in the mixed layer at SEATS site in the northern SCS.

\section{CONCLUSIONS}

A better assessment of seasonal and inter-annual variability of $\mathrm{CO}_{2}$ fluxes in different oceanic regimes is a premise for adequately quantifying the global oceanic $\mathrm{CO}_{2}$ uptake. However, our present knowledge from time-series studies has been largely achieved by stud- 
ies in the open ocean (e.g., BATS and HOT), with scant attention to the marginal seas. In this study, we report, for the first time, the seasonal variations of carbon system at the SEATS time-series site in the northern South China Sea, based on the measurements from March 2002 to April 2003. Results show that the seasonal pattern of $\mathrm{NTCO}_{2}$ in the mixed-layer is characterized by a progressive decline from spring to early fall and by a subsequent increase in fall and winter. This seasonal variability of $\mathrm{NTCO}_{2}$ is mainly due to biological utilization in springsummer, and to strong vertical mixing in fall-winter, respectively. The seasonal changes of $\mathrm{fCO}_{2}$, however, are nearly opposite to that of $\mathrm{NTCO}_{2}$. The observed $\mathrm{fCO}_{2}$ augmentation in spring-summer appears to be primarily the result of temperature increases, despite the fact that about $60 \%$ of such a temperature effect is compensated by biological utilization. In the fall and winter, the temperature effect dominates over the combined effects of subsurface water entrainment and biological production, giving rise to diminishing $\mathrm{fCO}_{2}$ during the cooling period.

By comparison, our data show that the shallower thermalcline, nutricline and $\mathrm{TCO}_{2}$-cline at SEATS have resulted in a greater extent of biological and temperature effects on $\mathrm{fCO}_{2}$ variations than at HOT. According to the seasonal $\mathrm{fCO}_{2}$ distributions, surface waters at the SEATS site act as an atmospheric $\mathrm{CO}_{2}$ sink in winter, yet a source in summer and fall during the observed period. Over the annual cycle, however, a net sea-to-air $\mathrm{CO}_{2}$ flux is estimated to be $-0.11 \pm 0.08$ to $-0.23 \pm 0.18 \mathrm{molC} \mathrm{m}^{-2}$ year $^{-1}$. In response to the observed $\mathrm{NTCO}_{2}$ drawdown, an estimated net community production of $6.8 \pm 0.77 \mathrm{mmolC} \mathrm{m}^{-2} \mathrm{year}^{-1}$ in the mixed-layer is obtained. The continuous spring-summer drawdown of $\mathrm{NTCO}_{2}$ with the absence of nitrate, however, suggests other sources of nitrogen are required to support the observed new production.

Acknowledgments We are grateful to the Captains, crew and technicians of $R / V$ Ocean Research I and III for assistance with deck operations and shipboard sampling, and to F. S. Lee and S. G. Lin for laboratory assistance. We thank K. K. Liu, L. S. Wen, F. K. Shiah, and the staff of the National Center for Ocean Research (NCOR) for cruise participation and logistic support during the course of this research, Y. L. L. Chen for constructive discussion on the nitrogen fixation, W. D. Liang for analysis of wind speed data, and B. S. Lee for providing the $\mathrm{TCO}_{2}$ and TA data of March 2002. We also thank R. Lukas and D. Karl (HOT project) for making potential temperature, phosphate, and total $\mathrm{CO}_{2}$ data at the HOT site available for use in this study. Constructive comments and suggestions from C. L. Wei and two anonymous reviewers greatly improved the manuscript. This work was supported by the National Science Council grants (NSC90- 2611-M-110-008-OP1 and NSC91-2611-M-110-003) to D. D. Sheu. The study is a contribution to the SEATS (South East Asia Time-series Study) program sponsored by NCOR, National Science Council, Republic of China.

\section{REFERENCES}

Bates, N. R., A. F. Michaels, and A. H. Knap, 1996: Seasonal and interannual variability of oceanic carbon dioxide species at the U.S. JGOFS Bermuda Atlantic-series Study (BATS) site. Deep-Sea Res. II, 43, 347-383. 
Bates, N. R., T. Takahashi, D. W. Chipman, and A. H. Knap, 1998: Variability of $\mathrm{pCO}_{2}$ on diel to seasonal timescales in the Sargasso Sea.J. Geophys. Res., 103, 15567-15585.

Bates, N. R., 2001: Interannual variability of oceanic $\mathrm{CO}_{2}$ and biogeochemical properties in the Western North Atlantic subtropical gyre.Deep-Sea Res. II, 48, 1507-1528.

Bates, N. R., and D. A. Hansell, 2004: Temporal variability of excess nitrate in the subtropical mode water of the North Atlantic Ocean. Mar. Chem., 84, 225-241.

Bradshaw, A. L., P. G. Brewer, D. K. Shafer, and R. T. William, 1981: Measurement of total carbon dioxide and alkalinity by potentiometric titration in the GEOSECS program. Earth Planet. Sci. Lett., 55, 99-115.

Butler, J. N., 1992: Alkalinity titration in seawater: how accurately can be the data be fitted by an equilibrium model? Mar. Chem., 38, 251-282.

Chao, S. Y., P. T. Shaw, and S. Y. Wu, 1996: Deep water ventilation in the South China Sea. Deep-Sea Res. I, 43, 445-466.

Chen C. T. A., and M. H. Huang, 1995: Carbonate chemistry and the anthropogenic $\mathrm{CO}_{2}$ in the South China Sea. Acta Oceanol. Sin., 14, 47-57.

Chen, C. T. A., and M. H. Huang, 1996: A mid-depth front separating the South China Sea Water and the Philippine Sea Water. J. Oceanogr., 52, 17-25.

Chen, C. T. A., S. L. Wang, B. J. Wang, and S. C. Pai, 2001: Nutrient budgets for the South China Sea basin. Mar. Chem., 75, 281-300.

Chen, C. T. A., S. L. Wang, W. C. Chou, and D. D. Sheu, 2005: Carbonate chemistry of the South China Sea. (submitted to Mar. Chem.)

Chen, Y. L. L., H. Y. Chen, D. M. Karl, and M. Takahashi, 2004: Nitrogen modulates phytoplankton growth in spring in the South China Sea. Cont. Shelf Res., 24, 527-541.

Copin-Montégut, C., 2000: Consumption and production on scales of a few days of inorganic carbon, nitrate and oxygen by the planktonic community: results of continuous measurements at the Dyfamed station in the northwestern Mediterranean Sea (May 1995). Deep-Sea Res. I, 47, 447-477.

Dickson, A. G., 1981: An exact definition of total alkalinity and a procedure for the estimation of alkalinity and total inorganic carbon from titration data. Deep-Sea Res., 28, 609623.

Dickson, A. G., and F. J. Millero, 1987: A comparison of the equilibrium constants for the dissociation of carbonic acid in seawater media. Deep-Sea Res. I, 34, 1733-1743.

Dickson, A. G., 1992: The development of alkalinity concept in marine chemistry.Mar. Chem., 40, 49-63.

DOE, 1994: Handbook of methods for the analysis of the various parameters of the carbon dioxide system in seawater. In: Dickson A. G. and C. Goyet (Eds.), U.S. Department of Energy $\mathrm{CO}_{2}$ science Team Report, version 2, (unpublished manuscript).

Dore, J. E., R. Lukas, D. W. Sadler, and D. M. Karl, 2003: Climate-driven changes to the atmospheric $\mathrm{CO}_{2}$ sink in the subtropical North Pacific Ocean. Nature, 24, 754-757.

Feely, R. A., C. L. Sabine, T. Takahashi, and R. Wanninkhof, 2001: Uptake and storage of carbon dioxide in the ocean: The Global $\mathrm{CO}_{2}$ survey. Oceanogr., 14, 18-32. 
Gong, G. C., K. K. Liu, C. T. Liu, and S. C. Pai, 1992: The chemical hydrography of the South China Sea west of Luzon and a comparison with the west Philippine Sea.Terr. Atmos. Ocean. Sci., 3, 587-602.

Goyet, C., F. J. Millero, D.W. O’Sullivan, G. Eischeid, S. J. McCue, and R. G. J. Bellerby, 1998: Temporal variations of $\mathrm{pCO}_{2}$ in surface seawater of the Arabian Sea in 1995. Deep-Sea Res. I, 45, 609-623.

Gruber, N., C. D. Keeling, and N. R. Bates, 2002: Interannual variability in the North Atlantic ocean carbon sink. Science, 298, 2374-2378.

Hansell, D. A., N. Bates, and D. B. Olson, 2004: Excess nitrate and nitrogen fixation in the North Atlantic Ocean. Mar. Chem., 84, 243-265.

Johnson, K. M., K. D. Wills, D. B. Butler, W. K. Johnson, and C. S. Wong, 1993: Coulometric total carbon dioxide analysis for marine studies: maximizing the performance of an automated gas extraction system and coulometric detector. Mar. Chem., 44, 167-188.

Karl, D. M., L. Letelier, L. Tupas, J. Dore, J. Christian, and D. Hebel, 1997: The role of nitrogen fixation in biogeochemical cycling in the subtropical north Pacific ocean. Nature, 386, 533-538.

Karl, D. M., J. E. Dore, R. Lukas, A. F. Michaels, N. R. Bates, and A. Knap, 2001: Building the long-term picture: the U.S. JGOFS Time-series Programs. Oceanogr., 14, 6-17.

Karl, D. M., N. Bates, S. Emerson, P. J. Harrison, C. Jeandal, K. K. Liu, J. C. Marty, A. F. Michaels, J. C. Miquel, S. Neuer, Y. Nojiri, and C. S. Wong, 2003: Temporal studies of biogeochemical processes in the world's oceans during the JGOFS era. In: Fasham, M. J. R. (Ed.), Ocean Biogeochemistry: The Role of the Ocean Carbon Cycle in Global Change, IGBP Book Series, Springer, 239-267.

Keeling, C. D., and T. P. Whorf, 2002: Atmospheric $\mathrm{CO}_{2}$ records from sites in the SIO air sampling network. In: Trends: A compendium of data on global change. Carbon dioxide information analysis center, Oak Ridge Nat. Lab., Tenn., U.S.

Lee, K., D. M. Karl, R. Wanninkhof, and J. Z. Zhang, 2001: Global estimates of net carbon production in the nitrate-depleted tropical and subtropical oceans. Geophys. Res. Lett., 29, 13-1-13-4.

Lewis, E., and D. W. R. Wallace, 1998: Program developed for $\mathrm{CO}_{2}$ system calculations, Carbon Dioxide Information Analysis Center, Report ORNL/CDIAC-105, Oak Ridge Nat. Lab., Tenn., U.S.

Liang, W. D., J. C. Jan, and T. Y. Tang, 2000: Climatological wind and upper ocean heat content in the South China Sea. Acta Oceanogr. Taiwanica, 38, 91-114.

Lin, H. L., L. W. Wang, C. H. Wang, and G. C. Gong, 1999: Vertical distribution of $\delta^{13}$ C of dissolved inorganic carbon in the Northeastern South China Sea.Deep-Sea Res. I, 46, 757-775.

Lin, I. I., W. T. Liu, C. C. Wu, G. T. F. Wong, C. Hu, Z. Chen, W. D. Liang, and K. K. Liu, 2003: New evidence for enhanced ocean primary production triggered by tropical cyclone. Geophys. Res. Lett., 30, 1781, doi:10.1029/2003GL017141.

Liss, P. S., and L. Merlivat, 1986: Air-sea gas exchange rates: introduction and synthesis. In: Buat-Menard, P. (Ed.), The role of air-sea exchange in geochemical cycling, NATO ASI Series C: Mathematical and Physical Sciences, 185, 113-128. 
Liu, K. K., S. Y. Chao, P. T. Shaw, G. C. Gong, C. C. Chen, and T. Y. Tang, 2002: Monsoonforced chlorophyll distribution and primary production in the South China Sea: observations and a numerical study. Deep-Sea Res. I, 49, 1387-1412.

Mehrbach, C., C. H. Culberson, J. E. Hawley, and R. M. Pytkowicz, 1973: Measurement of the apparent dissociation constants of carbonic acid in seawater at atmospheric pressure. Limnol. Oceanogr., 18, 897-907.

Michaels, A. F., N. R. Bates, K. O. Bueseler, C. A. Carlson, and A. H. Knap, 1994: Carboncycle imbalances in the Sargasso Sea. Nature, 372, 537-540.

Michaels, A. F., D. M. Karl, and A. H. Knap, 2000: Temporal studies of biogeochemical dynamics in oligotrophic oceans. In: Hanson, R. B., H. W. Ducklow, and J. G. Field, (Eds.), The Changing Ocean Carbon Cycles. Cambridge University Press, Cambridge, 393-413.

Michaels, A. F., D. M. Karl, and D. G. Capone, 2001: Element stoichiometry, new production and nitrogen fixation. Oceanography, 14, 68-77.

Millero, F. J., J. Z. Zhang, K. Lee, and D. Campelle, 1993: Titration alkalinity of seawater. Mar. Chem., 44, 269-280.

Neuer, S., R. Davenport, T. Freudenthal, G. Wefer, O. Linás, M. J. Rueda, D. K. Karl, and D. K. Steinberg, 2002: Differences in the biological carbon pump at three subtropical ocean sites. Geophys. Res. Lett., 29, doi:10.1029/2002GL015393.

Nitani, H., 1972: Beginning of the Kuroshio. In: Stommel, H., and K. Yoshida (Eds.), Kuroshio. Univ. Washington Press, Seattle, 129-163.

Quay, P., 2002: Ups and downs of $\mathrm{CO}_{2}$ uptake. Science, 298, 2344.

Sarma, V. V. S. S., M. Dileep Kumar, and M. D. George, 1998: The central and eastern Arabian Sea as a perennial source of atmospheric carbon dioxide.Tellus, 50, 179-184.

Sarma, V. V. S. S., M. Dileep Kumar, M. Gauns, and M. Madhupratap, 2000: Seasonal controls on surface $\mathrm{pCO}_{2}$ in the central and eastern Arabian Sea. Proc. Indian Acad. Sci., 109, 471-479.

Shaw, P. T., S. Y. Chao, K. K. Liu, S. C. Pai, and C. T. Liu, 1996: Winter upwelling off Luzon in the north-eastern South China Sea. J. Geophys. Res., 101, 16435-16448.

Shiah, F. K., K. K. Liu, and T. Y. Tang, 1999: South East Asia Time-series Station established in South China Sea. US JGOFS Newsletter, 10, 8-9.

Takahashi, T., J. Olafsson, J. G. Goddard, D. W. Chipman, and S. C. Sutherland, 1993: Seasonal variation of $\mathrm{CO}_{2}$ and nutrients in the high-latitude surface oceans: a comparative study. Global Biogeochem. Cycles, 7, 843-878.

Takahashi, T., R. A. Feely, R. A. Weiss, R. Wanninkhof, R. H. Chipman, D. W. Sutherland, and T. T. Takahashi, 1997: Global air-sea flux of $\mathrm{CO}_{2}$ : an estimate based on measurements of sea-air $\mathrm{pCO}_{2}$ difference. Proc. Natl. Acad. Sci., 94, 8292-8299.

Takahashi, T., S. C. Sutherland, C. Sweeney, A. Poisson, N. Metzl, B. Tilbrook, N. R. Bates, R. Wanninkhof, R. A. Feely, C. Sabine, J. Olafsson, and Y. Nojiri, 2002: Global sea-air $\mathrm{CO}_{2}$ flux based on climatological surface ocean $\mathrm{pCO}_{2}$, and seasonal biological and temperature effects. Deep-Sea Res. II, 49, 1601-1622. 
Tans, P. P., I. Y. Fung, and T. Takahashi, 1990: Observational constraints on the global atmospheric $\mathrm{CO}_{2}$ budget. Science, 247, 1431-1438.

Tseng, C. M., G. T. F. Wong, I. I. Lin, C. R. Wu, and K. K. Liu, 2005: A unique seasonal pattern in phytoplankton biomass in low-latitude waters: wind-reinforced (monsooninduced) winter convective overturn in the South China Sea. Geophys. Res. Lett., 32, L08608, doi:10.1029/2004GL022111.

Tsurushima, N., Y. Nojiri, K. Imai, and S. Watanabe, 2002: Seasonal variations of carbon dioxide system and nutrients in the surface mixed layer at station $\mathrm{KNOT}\left(44^{\circ} \mathrm{N}, 155^{\circ} \mathrm{E}\right)$ in the subarctic western North Pacific. Deep-Sea Res. II, 49, 5377-5394.

Wanninkhof, R., 1992: Relationship between wind speed and gas exchange over the ocean.J. Geophys. Res., 97, 7373-7382.

Winn, C. D., F. T. Mackenzie, C. J. Carrillo, C. L. Sabine, and D. M. Karl, 1994: Air-Sea carbon dioxide exchange in the North Pacific Subtropical Gyre: Implications for the global carbon budget. Global Biogeochem. Cycles, 8, 157-163.

Winn, C. D., Y. H. Li, F. T. Mackenzie, and D. M. Karl, 1998: Rising surface ocean dissolved inorganic carbon at the Hawaii Ocean Time-series site. Mar. Chem., 60, 33-47.

Wong, C. S., and Y. H. Chan, 1991: Temporal variations in the partial pressure and flux of $\mathrm{CO}_{2}$ at ocean Station P in the subartic northeast Pacific Ocean. Tellus, 43, 206-223.

Wong, G. T. F., S. W. Chung, F. K. Shiah, C. C. Chen, L. S. Wen, and K. K. Liu, 2002: Nitrate anomally in the upper nutrientcline in the northern South China Sea- Evidence for nitrogen fixation. Geophys. Res. Lett., 29, 12-1-12-4. 